\title{
EDitorial
}

\section{Curriculum: What, how and for whom?}

\section{Carol Mutch}

Curriculum is a hotly contested notion, yet it is a relatively new concept in educational thought. Pratt (1980) claims that it was only during the 20th century that attempts were made to describe, analyse and interpret curriculum as a phenomenon. Other writers (for example, Hargreaves, 1994) also claim that it took until the 1960s for it to become a substantial field of study within educational research and development. In the New Zealand context, Ivan Snook suggests that we did not have a tradition of curriculum theorising. He explains (1995, p. 167), "A sturdy pragmatism, liberal sentiment and political slogans have served in its place." Clive McGee's (1997) book, Teachers and Curriculum Decision-Making marked a key point in moving New Zealand curriculum theorising forward to the point where, over the last 20 years, we have seen it evolve into a common topic of deliberation and debate as policy makers, academics and practitioners contest definitions, challenge assumptions and bring different lenses to bear on the concept. The development of scholarly journals based in New Zealand, such as Curriculum Matters, helps keep these deliberations and debates to the fore, albeit with a continuing thread of sturdy pragmatism and liberal sentiment.

This issue of Curriculum Matters is released as schools take time to reflect on what curriculum means for them individually and collectively. The release of The New Zealand Curriculum (Ministry of Education, 2007) provided the opportunity for schools to design a curriculum for their own particular contexts. Some schools have embraced this challenge, while others are only beginning (Education Review Office, 2009). For those with an interest in curriculum as a phenomenon, these are exciting times. The development at a system-wide level and the design at a school-based level get to the heart of what "curriculum" is and how it can be interpreted. One of the most commonly cited models 
of curriculum construction is Ralph Tyler's (1949) rationale, which asked four major questions:

- What educational goals should schools seek to attain?

- How can learning experiences be selected which are likely to be useful in attaining these objectives?

- How can learning experiences be organised for effective instruction?

- How can the effectiveness of learning experiences be evaluated?

The New Zealand Curriculum (Ministry of Education, 2007) has provided one set of answers to these questions at a system-wide level through the vision, principles, learning areas, key competencies, teaching-as-inquiry cycle, assessment and so on. By February 2010, schools are expected to have asked themselves similar questions in relation to their particular student and community needs and interests and designed an evolving school-based curriculum in response.

The recent Education Review Office report on Readiness to Implement the New Zealand Curriculum (2009, p. 13) suggests that schools are at the stage of giving effect to the national curriculum through the following four questions:

- What is important and worth teaching?

- What are our students' current strengths, needs and experiences?

- What approaches and strategies should we plan for and implement to develop specific skills, concepts or attitudes?

- What is happening for students when we implement these strategies, how do we know this and what should we do next to promote student learning?

Both these sets of questions reveal the nuances of curriculum. It can be discussed at the societal or aspirational level-what is of most importance, what do we value as a society and what do we want our children and young people to become? It can be analysed at the political or official levelwhat does the government of the day or its agencies consider is of most importance as displayed in written documents, regulatory requirements or funding decisions? It can be filtered at the unit level (district, school type, governing body, institution)—given the particular philosophy, special character, location or school population, what is selected to be of 
most importance and what is ignored or rejected? What is the role of the community or set of stakeholders in this selection? Curriculum can be examined at the enacted level—what gets taught, assessed and reported on (and how)? How is this selection influenced by available resources, teacher knowledge, student need or interest? And, finally, at the impact level—what is learned, retained, assimilated, used, ignored, subverted, rejected or just forgotten?

How the multiplicity of local layered interpretations of curriculum will play out in New Zealand's educational history is a question of immense interest. Tyler's model, cited earlier, is seen as a "traditional" curriculum model in that it focuses on what and how. New Zealand's curriculum theorising, in its short history, has had a strong "reconceptual" focus, in that it asks "for whom?" How will the big questions of curriculumwhat, how and for whom? - be answered? Which approaches will prove to be more successful (and what do we mean by success)? What will the match between the aspirational and enacted curriculum be? Who will be the winners and losers?

The articles in this issue of Curriculum Matters cover the spectrum of curriculum questions-what, how and for whom?-from thinking about thinking and its place in the curriculum (Andy Begg) to asking what should be in a teacher education curriculum in and for the future (Lindsey Conner) or analysing the recent changes in number and algebra in the mathematics curriculum (Chris Linsell). As well as asking "what" should be in a curriculum, authors in this issue consider "how" it might be delivered. Myra Kunowski, for example, examines the use of case as a pedagogical strategy for teacher education students and Richard Manning makes a plea for place-based education to acknowledge the particular histories of a region. A strong theme in this issue also focuses on a curriculum "for whom"? How is Asia (Margaret Kitchen) and the Pacific (Tanya Wendt Samu) viewed through the lens of our curriculum? Is the curriculum accessible to disabled students (Gill Rutherford) and to what extent does the curriculum meet its obligations under the Treaty of Waitangi (Richard Manning)?

It is hoped that this issue will spark readers to reflect on their concepts of curriculum and ask themselves-what, how and for whom? 
As this is my first year as editor of Curriculum Matters, it is important to recognise those who have contributed to the success of the journal. Firstly, thanks go to Andy Begg, the first editor, for his steadfast work in getting Curriculum Matters underway and keeping it moving forward. Secondly, thanks go to the current editorial board and the various anonymous reviewers whose guidance and critique keeps up the standard of the contributions - with special mention of Jim Neyland who has recently retired from this role.

\section{References}

Education Review Office. (2009). Readiness to implement The New Zealand Curriculum. Wellington: Author.

Hargreaves, A. (1994). Critical introduction. In I. Goodson (Ed.), Studying curriculum (pp. 1-11). Buckingham, UK: Open University Press.

McGee, C. (1997). Teachers and curriculum decision-making. Palmerston North: Dunmore Press.

Ministry of Education. (2007). The New Zealand curriculum. Wellington: Learning Media.

Pratt, D. (1980). Curriculum design and development. New York: Harcourt Brace.

Snook, I. (1995). Re-forming the curriculum in New Zealand. In D. Carter \& M. O'Neill (Eds.), International perspectives on education reform and policy implementation (pp. 158-168). London: Falmer Press.

Tyler, R. (1949). Basic principles of curriculum and instruction. Chicago: University of Chicago Press.

\section{The author}

Carol Mutch is currently the Senior Advisor to the Chief Review Officer in the Education Review Office. Formerly a teacher, teacher educator and academic, Carol's research and writing interests are in educational policy, curriculum, educational research and evaluation, and social education. She is the author of Doing Educational Research: A Practitioner's Guide to Getting Started and editor of Challenging the Notion of "Other": Reframing Research in the Aotearoa New Zealand Context. 